\title{
WINTERING OF AN URBAN BAT (PIPISTRELLUS KUHLII LEPIDUS) IN RECENTLY OCCUPIED AREAS
}

\author{
Vitalit Hukov ${ }^{1,2,3^{*}}$, Olha Timofieieva ${ }^{1,4}$, Alona Prylutska $^{1,2}$, Olena Rodenko ${ }^{1,2}$, Marharyta \\ MoiseienKo $^{1}$, VAleria Bohodist ${ }^{1,5}$, AnAStasia DomansKa ${ }^{1,6}$, Anton Vlaschenko $^{1,2}$ \\ ${ }^{1}$ Bat Rehabilitation Center of Feldman Ecopark, 62340 Lesnoye, Kharkiv Region, Ukraine \\ ${ }^{2}$ Ukrainian Independent Ecology Institute, Plekhanov st., 4061001 Kharkiv, Ukraine \\ ${ }^{3}$ Biological department, V.N. Karazin Kharkiv National University, Svobody sq. 4, \\ 61077 Kharkiv, Ukraine \\ ${ }^{4}$ Institute of Environmental Sciences, Jagiellonian University, ul. Gronostajowa 7, \\ 30-387, Kraków, Poland \\ ${ }^{5}$ Bila Tserkva National Agrarian University, Veterinary Medicine department, \\ Stavishchanskaya st., 126, 09111, Bila Tserkva, Ukraine \\ ${ }^{6}$ Center of Clinical Veterinary, Alchevskih st., 38, Kharkiv, Ukraine
}

Abstract.

Urbanization is one of the main drivers of ecological change in the modern world. In most cases, species diversity in urban landscapes is lower than in natural ones; however, some groups of animals are able to exploit and benefit from urban habitat. Pipistrellus kuhlii s.l. is (P. k. lepidus according to recent taxonomic review), a common European urban bat, whose range has expanded on a wide scale in the last 40 years. Thought to originate in Central Asia, this species has extended its range throughout Eastern and Central and Europe (a distance of more than 2,500 km) in part by using human settlements as a habitat. This study examines the ecological features of P. k. lepidus in wintertime in the Eastern part of Ukraine, where this species has been living for 20 years. Thirty-nine winter records of $\mathrm{P}$. k. lepidus (1,301 individuals totally) were selected from the database of the Bat Rehabilitation Center of Feldman Ecopark, 19 of which were groups from 2 to 641 individuals. Pipistrellus $\mathrm{k}$. lepidus was found in various types of structures, but most often in administrative buildings (school buildings - 69\%). Records were usually obtained during renovation works (85\%), and the roosting sites were cavities between the wooden planks of window frames and a wall (75\%). The records were obtained in 26 settlements, from a village $\left(0,293 \mathrm{~km}^{2}\right.$ and 252 people) to the biggest cities in the country (Kharkiv and Odessa). The sex ratio in winter aggregation in adults varied from $47 \%$ to $61 \%$ of females and for this-year individuals from $48 \%$ to $58 \%$, respectively. The body mass at the end of the hibernation period (February/March) decreases for 17-20\% compared to the beginning of the period (December). Adult females have bigger body size (body mass and forearm length) ( $p$-value $<0.05)$. Our results showed that $\mathrm{P} . \mathrm{k}$. lepidus is capable of forming homogeneous, sedentary populations in all types of settlements in Ukraine for these twenty years. However, this choice of habitat means that the species faces a high mortality risk from humans during building renovation and insulation works or pest control actions.

Key words: bats; Pipistrellus kuhlii lepidus; urbanization; Ukraine; winter aggregation, roost sites, synurbic species.

\section{INTRODUCTION}

While cities may have existed for over five millennia, the last 50-70 years have witnessed not only an unprecedented growth in their number and size but also fundamental changes in their character (Adams et al. 2005, Grimm et al. 2008). These modern cities form a distinct environment that poses novel challenges for wild animals whose natural habitats they overlap. These challenges include extreme variations in topography and vegetation coverage, a distinct microclimate and hydrologic profile, as well as noise, light, and industrial pollution. Consequently, urban environments tend to exhibit reduced vertebrate and invertebrate diversity as compared to rural and natural landscapes (McKinney 2008; Grimm et al. 2008). Nevertheless, some species are able to adapt for the urban environment and benefit from heat islands, heterogeneous landscapes, a variety of roosting-sites possibilities, and the reduced pressure from predators (e.g. Russo \& Ancillotto 2015).

Bats are a diverse group in urban areas, one of the highest among mammals, and many bat species 
have adapted well to life in the urban habitat (Jung \& Threlfall 2016). The urban environment is rich in the kind of shelters preferred by bats. The plethora of buildings and other constructions in urban landscapes provide a very diverse roosting sites for bats both breeding and hibernation seasons (Russo \& Ancillotto 2015; Voigt et al. 2016; Kravchenko et al. 2017a). The shelters in buildings mimic the naturally prefer roosting sites as cliffs, caves, and trees. Besides, the warmer conditions of the urban microclimate may be beneficial for bats energy consumption (Kerth et al. 2001; Lausen \& Barclay 2006a; Voigt et al. 2016), and the light pollution may contribute to increased prey density by attracting flying insects (Voigh et al. 2019). Though many European bat species could be classified as synurbic beneficiaries (e.g. Eptesicus serotinus, Hypsugo savii, Pipistrellus kuhlii) of the urban landscape (Jung \& Kalko 2011; Jung \& Threlfall 2015; Voigt et al. 2016), one of such examples is $P$. kuhlii, which is commonly found in cities and towns (Ancillotto et al. 2015).

Pipistrellus kuhlii sensu lato has a vast range that covers the entirety of the Mediterranean basin, much of southern Europe, and extends through Anatolia as far east as the Himalayan foothills in Pakistan and northwards across the Caucasus onto the Eurasian steppe (Bogdanowicz 2004; Juste \& Paunovic 2016). Within this range, the $P$. kuhlii species group includes several morphological and genetic forms the taxonomic status of which is still subject to debate (e.g. Benda et al. 2015; Andriollo et al. 2015; Sachanowicz et al. 2017). In Europe, two forms have been clearly described P. k. kuhlii and P. k. lepidus (Sachanowicz et al. 2017). The first resides throughout the Mediterranean basin, while the second is found chiefly in Eastern Europe and SE Asia. According to Sachanowicz et al. (2017) both of these forms are undergoing range expansion in opposite directions with P. k. kuhlii moving from the Mediterranean to the northeast, while $P$. $k$. lepidus is expanding from Central Asia towards the northwest. These two subspecies are sympatric and their current ranges overlap in eastern Slovakia and Hungary (Sachanowicz et al. 2017).

Considering this, it is likely that most previous research from Southern Europe and around the Mediterranean has focused on P. k. kuhlii (e.g. Benda et al. 2015, Russo \& Ancillotto 2015), while the natural history and ecological features of $P$. $k$. lepidus have been poorly studied. Moreover, comparing these two stories of range expansion, it looks like $P$. $k$. lepidus was moving faster, and it is a question of what specific ecological or morphological features allowed this bat taxon to achieve it. There are plenty of publications about "the first record" of this species in some settlement in Eastern (e.g. Kondratenko 1999; Gavris \& Kotserzhinska 2002; Lada 2010; Smirnov et al. 2012) and Central Europe (e.g. Celuch \& Ševčik, 2006; Popczyk et al. 2008; Michálek et al. 2017), but published data about the ecology of this taxon are available in limited sources (Strelkov et al., 1985; Rakhmatullina 2005; Smirnov \& Vehnik 2011; Bilushenko 2013).

Pipistrellus kuhlii lepidus the subject taxon of this paper has undergone extraordinary range expansion in the last 50-40 years. Originating in the desert areas of Central Asia the range of $P$. $k$. lepidus in the 1970s was limited to the territory of present-day Turkmenistan (Strelkov 1973) and the Southern Caucasus (Strelkov et al. 1985). By the late 1980s P. k. lepidus had crossed the Caucasus Mountains and could be found on the steppes well within the modern-day borders of the Russian Federation (Strelkov et al. 1985). In the latter paper (Strelkov et al. 1985) the prediction was made that this taxon would eventually occupy the entire Eurasian steppe down to the west of the Ural Mountains. However, by the late 1990 s, P. k. lepidus was well on its way to fulfilling this prediction and the species was found in the forest-steppe and forest zones of Ukraine (Sachanowicz et al. 2009) and the Russian Federation (Sachanowicz et al. 2009, Smirnov \& Vehnik 2011). Throughout the 2000s $P$. $k$. lepidus continued its westward range expansion across the entirety of Ukraine and could be found as far west as Poland (Sachanowicz et al. 2009). This range expansion is still ongoing and the 2010s have seen this subspecies move northward, and it can now be found in every part of Ukraine, on over half the territory of Belarus and in European Russia as far north as Moscow (Prylutska \& Vlaschenko 2013; Shpak \& Larchenko 2016; Sachanowicz et al. 2017). Meanwhile in Central Europe P. k. lepidus has reached as far west as Poland and Slovakia (Sachanowicz et al. 2017). Strelkov's prediction described this taxon as a steppe and semi-arid biomes associated bat (Strelkov et al. 1985). However, the full story of the range expansion of $P$. $k$. lepidus shows that this bat strongly associated with various types of human settlements, regardless of in what biome they are located. We assume that possibly the rapid 
range expansion exhibited by $P$. $k$. lepidus is due to its ability to use human buildings and other constructions as roosting sites and, vary of rural and urban landscapes as hunting habitats. However, what are ecological features made Pipistrellus $k$. lepidus successful synurbic species is poorly known. Describing the ecological features of $P$. k. lepidus in the recently occupied parts of its range is thus an important contribution to our knowledge about bat adaptations for human transformed environment. By this paper we contribute three main topics of P. k. lepidus winter ecology from different settlements throughout Eastern Ukraine: (i) the parameters of roosting buildings and roosting sites, (ii) numbers and sex-age structure of hibernation aggregations, (iii) body mass and forearm length of different sex age groups and groups from different settlements.

\section{Materials ANd Methods Study area}

The area from which records were obtained included settlements in the vast territory of Eastern Ukraine (Fig. 1). The study area stretches from the Ukrainian south steppe region (mean annual temperature $+10,1^{\circ} \mathrm{C}$ ) to the northern forest region (Polissia) (mean annual temperature $+8,1^{\circ} \mathrm{C}$ ). The northeasternmost point of the study area is Dvorichna town (N49.849921, E37.682740) in Kharkiv oblast, the northwesternmost is Vilne village (N50.215820, E29.779836) in Kyiv oblast and the southernmost is Odessa city (N46.476343, E30.722821) in Odessa oblast, while the easternmost is Lysychansk (N48.861301, E38.475366) in Luhansk oblast.

\section{Data collection}

The Bat Rehabilitation Centre of Feldman Ecopark (BRC-FE) is the premier organization engaged in bat rescue and rehabilitation in Ukraine (Vlaschenko and Prylutska 2018). The Center works under the permission of the Kharkiv Oblast Authority of Ecology and Natural Resources, and Ethical Commission of V.N. Karazin Kharkiv National University. Its call centre allows citizens to submit reports about bats in need of rescue throughout the country and arrange for delivery to the BRC-FE. All bats (alive or deceased) arriving at the centre have their sex, age category, reproductive status, point of origin, forearm length (accuracy $0.1 \mathrm{~mm}$ ) and body mass (accuracy $0.1 \mathrm{~g}$ ) recorded and are subsequently banded according to the accepted protocol (Vlaschenko et al., 2020). We used
2 age group classifications: ad $=$ adult $($ specimens older than 1 year), and first-year individuals (specimens younger than 1 year). For details of the methods used for age group classification see Kravchenko et al. (2017a). The subject of this study are 39 records (individuals and groups) of $P$. $k$. lepidus that arrived at the BRC-FE in a period between November 16 and March 15 each year during 2013-2020 (for the year 2020 with data for February included).

In addition, the following information was recorded where available for each of the 39 records that are the subject of this study.

1) The type of building in which the bats were found, grouped into the following categories: a) Industrial buildings (factories, warehouses, etc.); b) Administrative buildings (such as public schools or office buildings); c) Residential buildings (individual houses or apartments). 2) The construction material of the building of origin, broken down as follows: a) Concrete prefabricated block buildings; b) Brick buildings. 3) The height of the building: a) Low-rise (one or two storeys); b) Mid-rise (three to five storeys); c) High-rise buildings (six to ten storeys); d) Multi-storey buildings (eleven and more storeys). 4) Where within the building the bats were found: a) On a balcony or loggia; b) Between the panes of a window; c) In a cavity between wooden planks of window frames and a wall (behind frames) (see Fig. 2).

A total of 39 records of $P$. $k$. lepidus, obtained from 26 settlements of Ukraine (Fig.1) were selected for this study. The full list of records is presented in Table 1 of the Appendix. Records originated from a

Table 1. Results of binomial test for corresponding sex ratio into 9 groups to 1:1 for both ages (see: Appendix).

\begin{tabular}{|l|l|l|}
\hline \multirow{2}{*}{ Group } & \multicolumn{2}{|l|}{-value } \\
\cline { 2 - 3 } & adult & first-year \\
\hline 8 & 0.21 & - \\
\hline 14 & 0.33 & - \\
\hline 15 & - & 1 \\
\hline 16 & $<0.05$ & $<0.05$ \\
\hline 18 & $<0.05$ & 0.55 \\
\hline 20 & $<0.05$ & 0.33 \\
\hline 29 & 1 & 0.15 \\
\hline 31 & 0.1 & 0.15 \\
\hline 38 & 0.4 & $<0.05$ \\
\hline
\end{tabular}




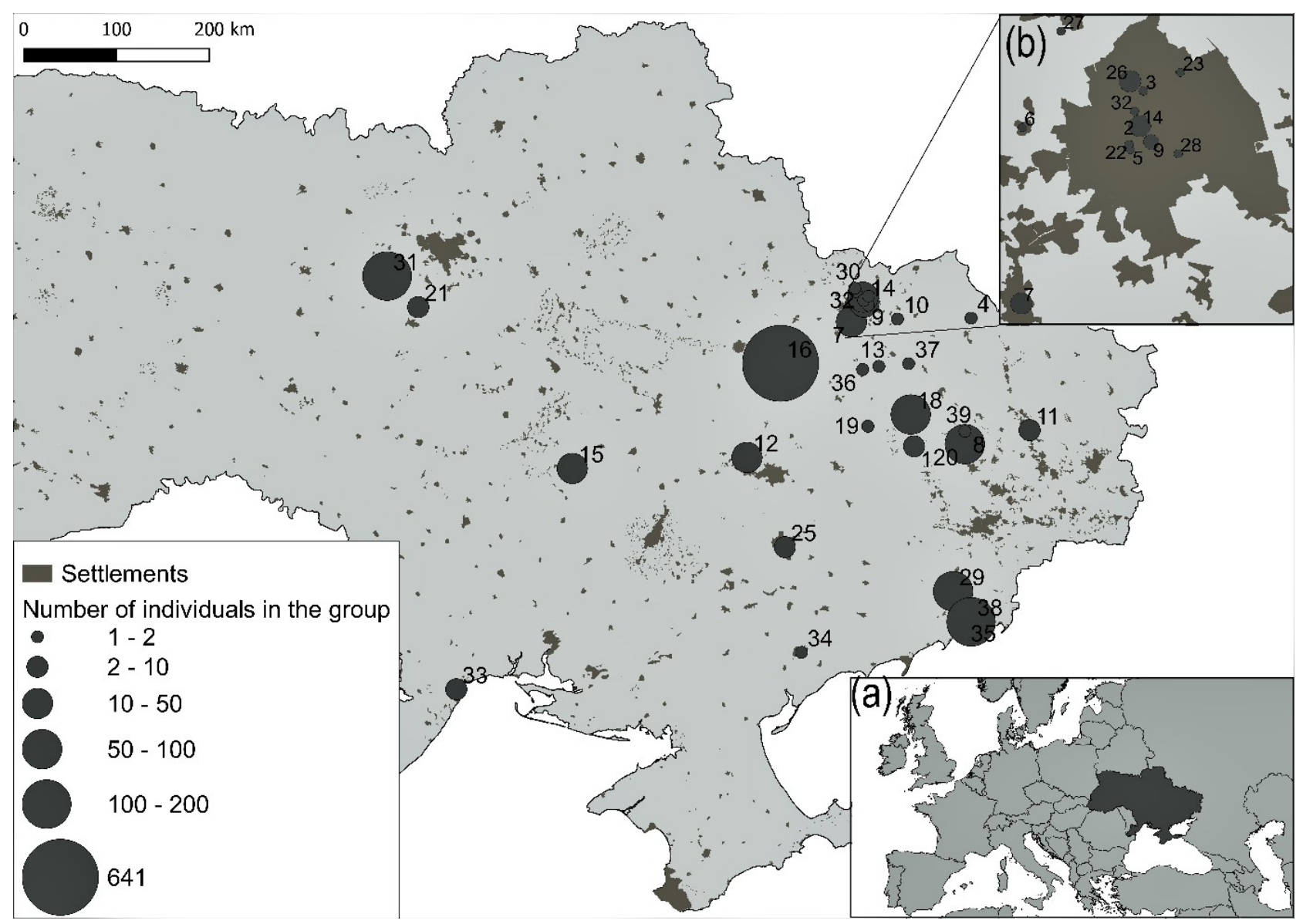

Figure 1. The map of the catchment area of records of $P$. $k$. lepidus in wintertime in Eastern Ukraine, and obtained to the Bat Rehabilitation Center of Feldman Ecopark during 2013-2020 (a) - general view of Ukraine, (b) - detailed map of records distribution in Kharkiv city and surroundings).

variety of settlements ranging in size from little villages (less than $1 \mathrm{~km}^{2}$ and a population of a few hundred people) to large urban centres including two of the biggest cities in Ukraine (Kharkiv and Odessa).

The raw dataset consisting of 1,301 of individual P. kuhlii has been uploaded to Global Biodiversity Information Facility. General data on bats' records can be viewed in the file "Occurrences" while data on bats' measurements is located in the file "Measurementorfact" (Hukov et al. 2020).

Examination of the external morphological characteristics, according to the description made by Sachanowicz et al. 2017 showed that all 1,301 individuals were without any doubts $P$. $k$. lepidus (this was evident from the width of the pale wing margin and the coloration of fur on the muzzle and in the groin area). This-year-born individuals were identified by their brownish and darker coloration as compared to adults.

\section{Statistical analysis}

Bats were separated into categories by age $(<1$ year and $>1$ year) and by the number of members in their group $(<20$ individuals or $>20)$ and the sex ratio was analyzed for significant deviation from a baseline of 1:1 for all groups and all bats combined. The data was analyzed using the one-tailed binomial test with groups of less than ten individuals being excluded from the analysis. Generalized linear models (GLM) with binomial distribution were used to assess the impact of other factors such as latitude, longitude, and are of settlement on the sex ratio of both age groups.

Six groups consisting of more than 45 individuals received during 2015-2020, were selected for forearm length and body mass analysis. Mean $(x)$, standard deviation (SD), and minimal/maximal value of forearm length and mass were calculated by sex.

We built two linear models (LMs) for forearm length using the location of find (settlement), sex and 
age as predictors in first LM, and the level of light pollution at the location of find (data from 2018), sex, and age in the second LM. LM were also built for body mass where predictors were sex, age, and a month of finding. In one case, several individuals from a location where numerous groups were found were transported to BRC-FE some days later, there- by body mass of these bats was not included in the analysis. The data were analyzed using multiple regression analysis.

Body mass loss during winter (from December to February) for four sex-age groups was calculated and as a percentage using LM: body mass $=$ month + sex + age.
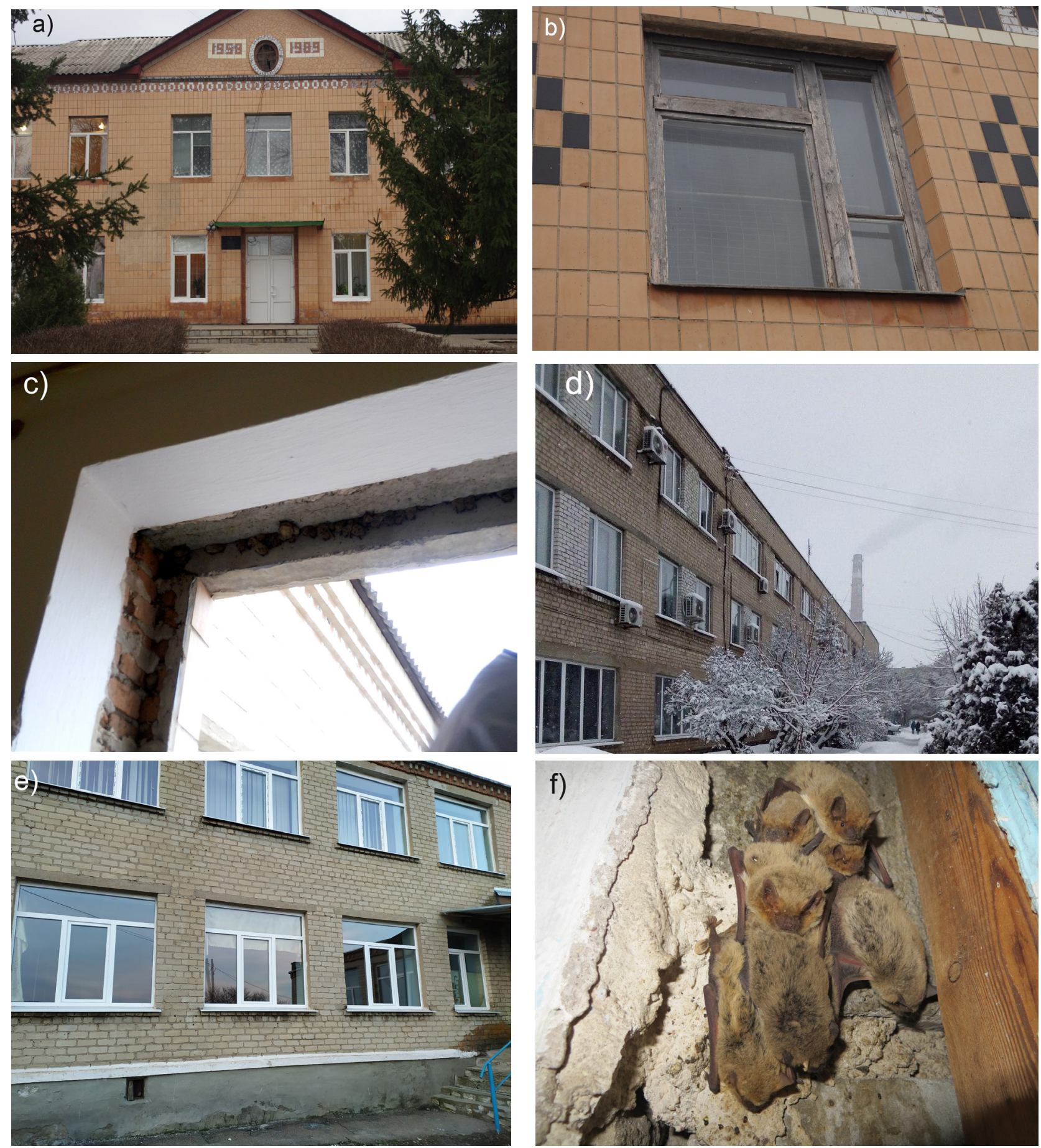

Figure 2. Examples of P. $k$. lepidus hibernation buildings and roosts (a-c - Karlivka village (record № 16), d - Lozova village (record №19), e-f - Sonyachne village (record №29)). 
Microsoft-Excel and R software (version 3.5.1, $\mathrm{R}$ Core Team 2018) were used to conduct the statistical analysis. The statistical tests were considered significant when $\mathrm{P} \leq 0.05$.

\section{RESULTS}

Combined the records contained 1301 individuals, 20 of these records consisted of only one individual while the remainder ranged in from 2 to 641 bats. In the total sample females (891 bats) and this-year individuals (681 bats) dominated.

\section{Roosting sites}

Most of the records were found in administrative buildings $(\mathrm{n}=15)$, fewer but significant numbers $(\mathrm{n}=13)$ were found in residential buildings, and the fewest $(n=7)$ originated from industrial buildings (Fig. 3a).

The proportion of records originating from panel blocks $(n=10)$ was far fewer than that of found in brick buildings $(n=19)$ (Fig. 3b). A third of the records were found in low-rise buildings $(n=13)$, second in the number of records were mid-rise buildings $(n=11)$, and only a few records originated from highrise $(n=6)$ and multi-story ( $n=1)$ (Fig. 3c). Fifty-sev- en percent of records were found on either the first or second floor, while the highest floor where reported records is the eleven's floor.

Most records of $P$. k. lepidus were found behind frames $(n=18)$, inside windows $(n=4)$, and only a single record was found on a balcony $(\mathrm{n}=1)$ (Fig. 3d).

\section{Structure and sex ratio}

Just over half of the records of $P$. $k$. lepidus included only a single individual. In general, the number of individuals in groups varied from 2 to 144 . Only a single group contained 641 members (Fig. 4).

Sex ratio in the whole sample $(n=1301)$ was female-dominated (Fig. 5a) and differed significantly from 1:1 (binomial test, $\mathrm{p}<0.05$ ) for both age groups. However in bats found individually or in small groups $(\mathrm{n}=101)$ sex ratio for both age groups was not significantly different from 1:1 (binomial test, $\mathrm{p}>0.05)$ (Fig. 5b).

In large groups (20 or more individuals) the sex ratio was female-dominated for both age groups (Fig. $6 \mathrm{~A}, \mathrm{~B})$. The highest proportion of males among adult individuals ranged from 39 to $53 \%$ and occurred in three groups (Fig. 6a, cases: 29 - Sonyachne village, 31 - Vilne village, 38 - Mariupol city). In the other

(b)

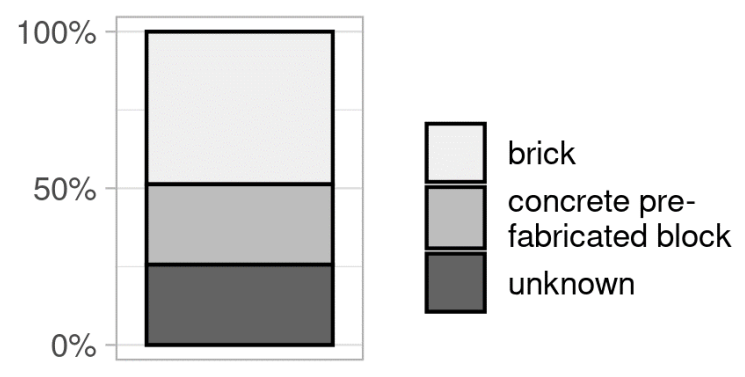

(d)

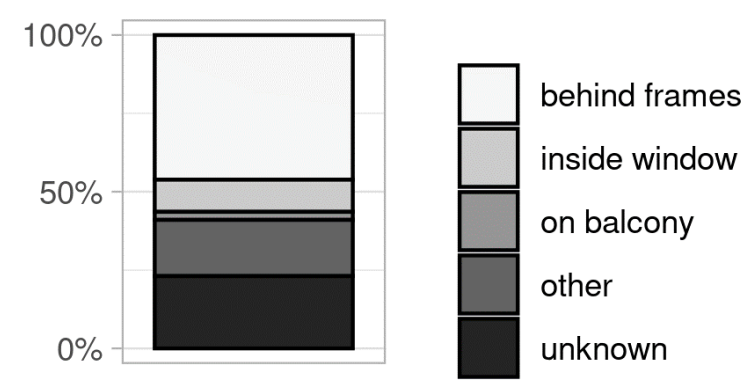

Figure 3. Proportions of buildings and roosting sites where groups of $P$. $k$. lepidus were found during 2013-2020, grouped by type: (a) - type of buildings, (b) - type of building materials, (c) - height of buildings, (d) - types of roosting sites. 


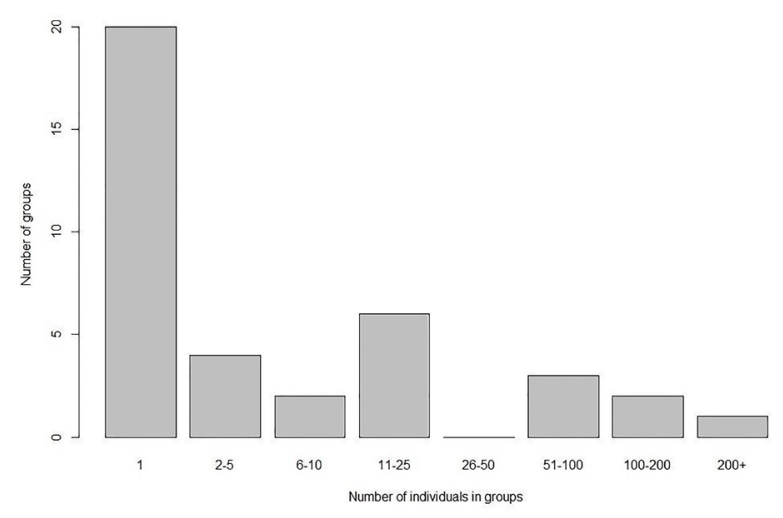

Figure 4. Number of $P$. $k$. lepidus found individually or in groups in wintertime and obtained by the Bat Rehabilitation Center of Feldman Ecopark during 2013-2020 from 26 settlements of Ukraine.
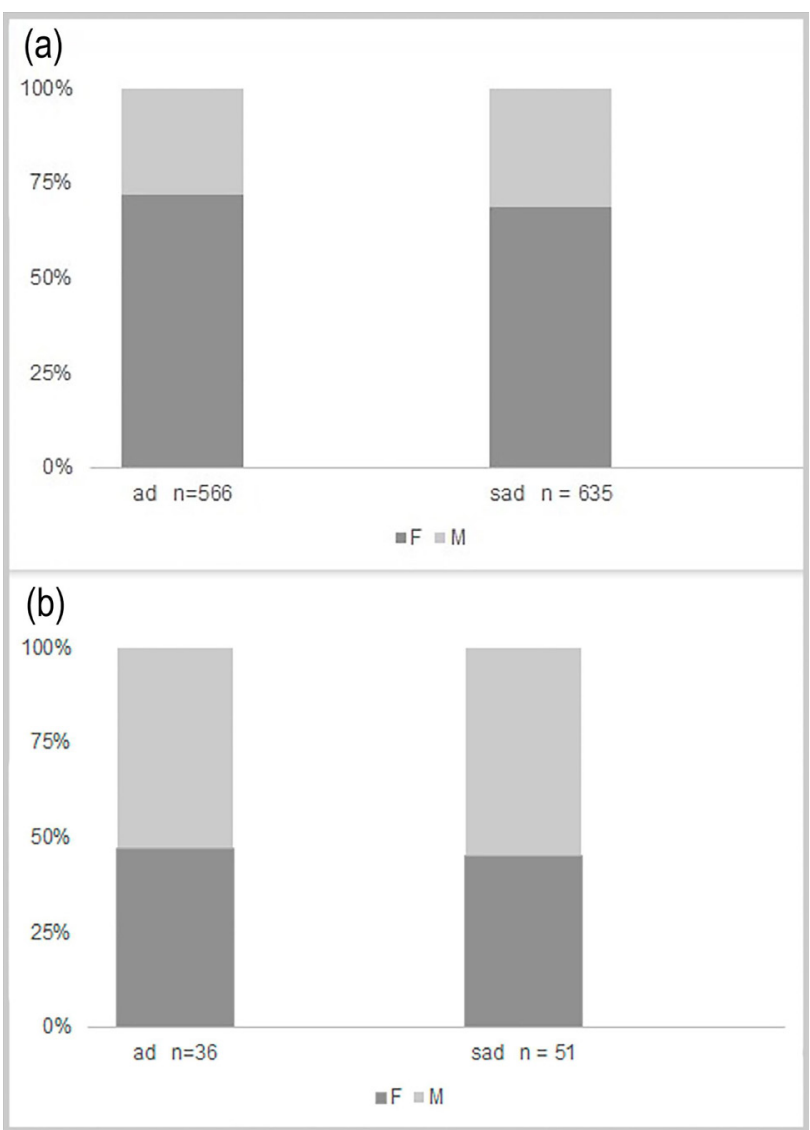

Figure 5. Sex ratio for the whole sample of $P$. $k$. lepidus combined ( $\mathrm{n}=1301)(\mathrm{a})$, and for bats found individually or in small groups (b). Bats were obtained by the Bat Rehabilitation Center of Feldman Ecopark in wintertime during 2013-2020 from different settlements of Ukraine (n - number of individuals in each sample; ad - adult, sad - this-year individuals).

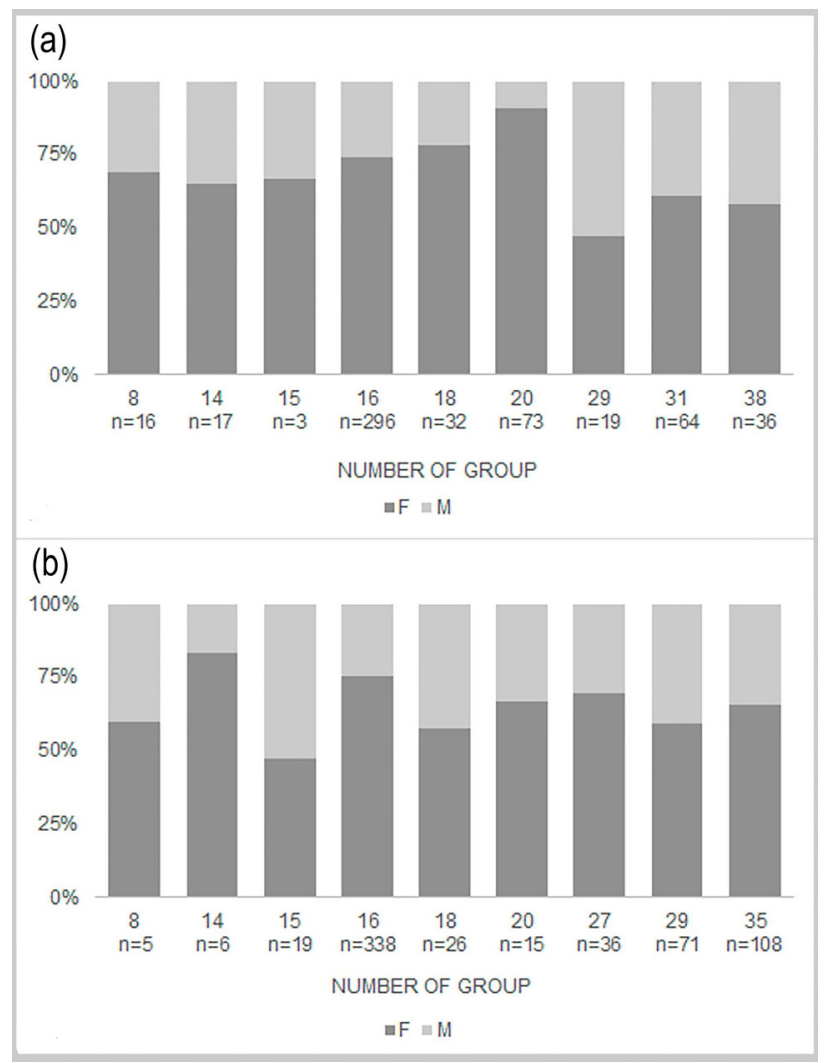

Figure 6. Sex ratio by age and group in adult (a) and firstyear $P$. k. lepidus (b) across 9 different groups obtained in wintertime during 2013-2020 from different settlements of Ukraine numbers under columns are order number of a group according to Appendix; $\mathrm{n}$ - number of individuals in each sample).

groups adult females dominated, comprising up to $90 \%$ of the group (Fig. 6a, cases: 20 - Kramatorsk town).

Among first-year individuals, the highest proportion of males ranged from $42 \%$ to $52 \%$ in three groups (Fig. 6b, cases: 8 - Kramatorsk town, 15 Kropyvnytskyj city, 18 - Druha Ivanivka village). In the other groups, females numerically dominated, composing up to $80 \%$ of the total in cases 16 (Karlivka village) and 38 (Mariupol city).

Only groups 16,18 , and 20 showed statistically significant deviations from a 1:1 sex ratio among adult individuals ( $\mathrm{p}$-value $<0.05$ ). Meanwhile groups 16 and 38 showed a statistically significant deviation from a 1:1 sex ratio among first-year individuals (p-value $<0.05$ ) (Table 1).

The area of settlements did not significantly impact the sex ratio in groups ( $\mathrm{z}$-value $=0.42, \mathrm{p}$-value $>0.5$ for adult and $z$-value $=-0.31, p$-value $=0.75$ for first-year individuals). But longitude (z-value $=$ $-3.64, p$-value $<0.001$ for adult and $\mathrm{z}$-value $=-3.73$, 
p-value $<0.0001$ for first-year individuals) and latitude $(\mathrm{z}$-value $=-2.82$, p-value $<0.005$ for adult and $\mathrm{z}$-value $=-2.62, \mathrm{p}$-value $<0.001$ for first-year individuals) have significant impact in sex ratio. The proportion of females decreases with increasing longitude and latitude. Thus, the proportion of females of both ages decreases from North to South and from East to West (Table 2).

Table 2. Results of logistic regression analysis of the GLM model. For modeling females were labeled as 1 , males as 0 .

\begin{tabular}{|l|l|l|l|l|}
\hline Factor & Estimate & SE & z-value & p-value \\
\hline Adult \\
\hline (Intercept) & 31.81 & 10.41 & 3.05 & 0.002 \\
\hline Area & 0.0005 & 0.001 & 0.42 & 0.67 \\
\hline Latitude & -0.51 & 0.18 & -2.82 & 0.004 \\
\hline Longitude & -0.21 & 0.05 & -3.64 & 0.0002 \\
\hline First-year individuals \\
\hline (Intercept) & 30.8 & 10.67 & 2.88 & 0.003 \\
\hline Area & -0.0005 & 0.001 & -0.31 & 0.75 \\
\hline Latitude & -0.49 & 0.19 & -2.62 & 0.008 \\
\hline Longitude & -0.2 & 0.05 & -3.73 & 0.0001 \\
\hline
\end{tabular}

\section{Body mass and forearm length analysis}

Results of LM show that female individuals have significantly longer forearm length (intercept: 35.98, standard error: 0.07 , t-value: 453.57 , p-value $<0.001$ ) than males (p-value $<0.001$ ) (Fig. 7). There was no significant difference between individuals of both ages ( $p$-value $>0.2$ ) and was detected that individuals from Druha Ivanivka village (group number 18) had significantly smaller forearm length than bats from other locations ( $\mathrm{p}$-value $<0.01$ ). Differences in forearm length between all other locations were not significant ( $p$-value $>0.05)$. Level of light pollution is not significant ( $p$-value $>0.1$ ) impacted on forearm length. The mean forearm length for all females - 36 $\mathrm{mm} \pm 1.5$ (range: $31.8-39 \mathrm{~mm}$ ), and for males - 35.5 $\mathrm{mm} \pm 0.8$ (range: $33.2-37.8 \mathrm{~mm}$ ).

There were statistically significant differences between sex ( $\mathrm{p}$-value $<0.001)$ and age ( $\mathrm{p}$-value $<$ 0.001 ) for body mass (intercept: 6.83, standard error: 0.07, t-value: 88.980 , p-value $<0.001$ ). Between body mass in March and February were not detected significant differences ( $p$-value $>0.05$ ) and in De-

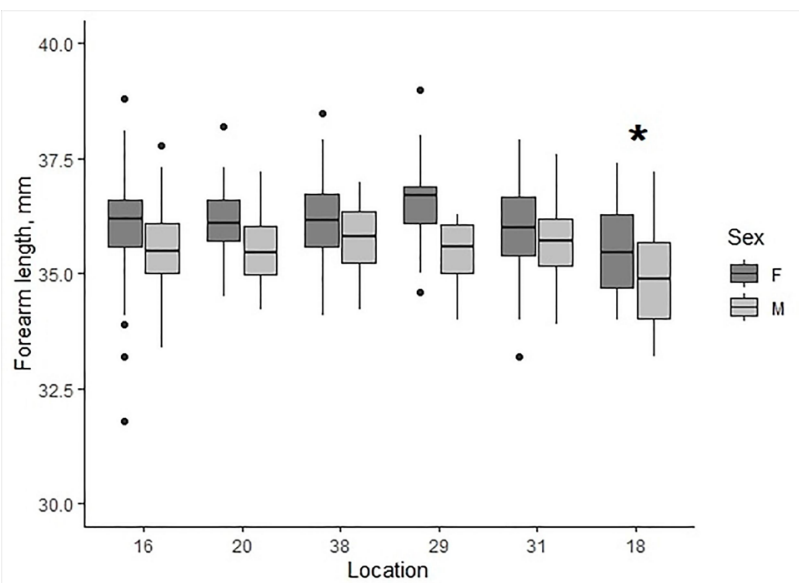

Figure 7. Forearm length (in $\mathrm{mm}$ ) sex of $P$. $k$. lepidus gathered over 2015-2020 from different locations in Eastern Ukraine Boxplot rectangle - 1st and 3rd quartiles, whiskers - one and half of box length, thick line - median, circles - outliers; * - statistically significant difference.

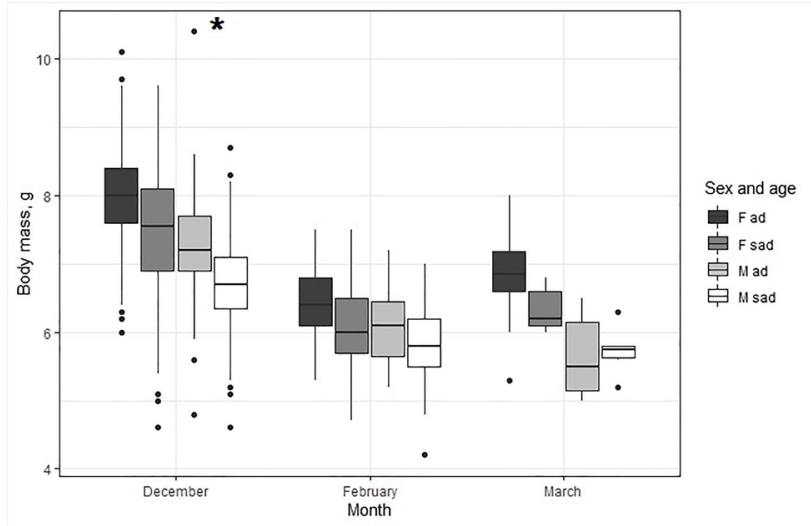

Figure 8. Body mass of $P$. k. lepidus (in g) by age and sex as measured in December, February and March (20152020) in Eastern Ukraine (ad - adult; sad - first-year individuals). Boxplot rectangle - 1st and 3rd quartiles, whiskers - one and half of box length, thick line - median, circles - outliers; * - statistically significant difference.

cember, the value of body mass was significantly higher than in other months ( $p$-value $<0.001$ ). Adult females had significantly higher body mass than other sex-age groups and first-year males had the lowest one regardless of a month (Fig. 8).

In December mean values of body mass of bats is $7.9 \mathrm{~g}$ for adult females, $7.4 \mathrm{~g}$ for first-year females, $7.3 \mathrm{~g}$ for adult males, and $6.8 \mathrm{~g}$ for first-year males. In February body mass decreases to $6.6 \mathrm{~g}, 6.1 \mathrm{~g}$, $6.0 \mathrm{~g}, 5.5 \mathrm{~g}$, respectively and throughout the entire winter, all bats lose from 17 (adult females) to 20\% (first-year males) of their body mass by December. The full results of the multiple regression analyses are presented in the Appendix. 


\section{DiscuSSION}

This study presents the first detailed description of winter aggregations and winter roost sites of $P$. $k$. lepidus living in Eastern Ukraine, an area where this bat taxon appeared only 20 years ago due to rapid range expansion. Thus, this bat with Asian roots (e.g. Strelkov et al. 1985; Sachanowicz et al. 2017) appeared in parts of Eastern Europe and has become a common sedentary species in most human settlements (Bilushenko 2013; Prylutska \& Vlaschenko 2013; Gashchak et al. 2013; Godlevska \& Rebrov 2018). Despite the well-documented history of this species' rapid expansion (e.g. Strelkov et al. 1985; Sachanowicz et al. 2009; Smirnov \& Vehnik 2011), the ecological particularities and natural history of this species in recently occupied areas is poorly described. We aim to contribute to the growing body of data about wintering of this species because winter season is a critical period for bats living in temperate and boreal latitudes. Under natural conditions $P$. kuhlii s.l. is thought to be a relatively sedentary species, with a maximum movement range of about 5 $\mathrm{km}$ (Hutterer et al. 2005). However, this species has been recorded sheltering in human transports (trucks, ships, cars, and trains) and being inadvertently moved far from its native range (Hutterer et al. 2005; Smirnov \& Vehnik, 2011). In all its years of operation, the BRC-FE has documented only one recapture of a previously ringed $P$. $k$. lepidus in the Kharkiv city area. An adult male was recaptured after eight months 10 $\mathrm{km}$ from the release location, it had moved inside a densely built-up area for hibernation (not included in this study). We hypothesized that all winter records of $P$. k. lepidus in human settlements are evidence of sedentary local populations of this species. Moreover, according to results of summer mist-netting in Ukraine, this species is extremely rare or wholly absent in natural habitats such as woodlands and floodplains (e.g. Kovalov et al. 2019; Godlevska \& Rebrov 2018) but relatively common on the periphery or inside settlements (e.g. Vlaschenko et al. 2012; Hukov et al. 2019). Volunteers who captured individuals and groups of $P$. $k$. lepidus (reported in this study) during renovation works and delivered them to BRC-FE often mentioned that the bats live in that buildings all year-round. Probably P. k. lepidus from each of human settlements live sedentary there, and maybe even with year-round home fidelity to a roosting building. However, this information is has to be proved by future studies.

\section{Roosting sites}

The distribution of wintering $P$. $k$. lepidus groups across different types of buildings observed in this study are similar to those seen in past studies (Strelkov \& Il'in 1990; Smirnov \& Vehnik 2011). Pipistrellus $k$. lepidus is frequently found on the lower floors of administrative brick buildings, and particularly school buildings (Fig. 3). While most of these studies have focused on summer colonies (Bilushenko 2013). Though, P. k. lepidus in winter can be found in practically all types of buildings. It may be said with a sufficient degree of confidence that they prefer administrative buildings. To some extent, this can be explained by the structural features common in buildings. For example, the schools' tend to possess large windows and are often older buildings resulting in numerous cavities within their superstructure. Furthermore, there is a very strong chance of finding the colony precisely in administrative buildings than in industrial buildings or private houses, which could bias our results. In accordance with previous reports (e.g. Godlevska 2015), most groups of $P$. $k$. lepidus featured in this study were found behind window frames (Fig. 4) during renovation work or window upgrades. In summary, $P$. $k$. lepidus in Eastern Ukraine tends to select winter roosts in semi-crevices or hollows between wooden window frames and an adjoining wall in low-rise brick buildings. However, the wide range of building types used by $P$. $k$. lepidus throughout Eastern Europe shows an opportunistic usage of local urban and rural landscapes without a strong preference for particular buildings, but only for roosting site characteristics (narrow semi-crevices and hollows).

\section{Structure and sex ratio}

There was no observed relationship between settlement size and bat aggregation number. While relatively few groups were found in the two largest cities, it cannot be said with certainty whether this is due to some preference of $P$. $k$. lepidus or a bias in the way bats were collected for this study. Past studies in Ukraine have shown that for the most part bats are encountered as single individuals or occasionally in small groups in winter. Cases of 15-20 individuals in a single group are present but rare (Rebrov 2012; Prylutska \& Vlaschenko 2013; Gashchak et al. 2013; Godlevska 2015; Godlevska \& Rebrov 2018; Panchenko \& Godlevska 2018), and no group of more than 50 (Zagorodniuk 2018) has been recorded. The 
larger groups (more than 50 individuals) of $P$. $k$. lepi$d u s$ reported in this paper (Fig. 4) are the largest ever described for this taxon. In a few cases $P$. $k$. lepidus was found together with Nyctalus noctula in winter roosting sites (Godlevskaya 2012). Interestingly, this bat taxon has been found to be present in abandoned towns of the Chernobyl Exclusion Zone (Northern Ukraine) year-round (Gashchak et al. 2013).

The sex ratio of European bat populations is a relatively well-described topic, especially sex-based segregation in summer habitats and roosts (e.g. Strelkov 1999; Rakhmatulina 2000; Russo 2002; Snit'ko 2007; Estók 2007; Vlaschenko 2008; Ibáňez et al. 2009). There is a hypothesis that the sex ratio in bat winter aggregations better reflects the real ratio in the total population (e.g. Strelkov 1999; Rakhmatulina 2000; Ibáňez et al. 2009). The reason is that bats of both sexes and age groups and from different areas join together after breeding season (e.g. Snit'ko 2007; Ibáňez et al. 2009). Additionally, previous studies have shown that in newly occupied areas bats tend to have a sex ratio skewed towards males (e.g. Vlaschenko 2008), possibly because first-year males are the main dispersal group in bat populations (Strelkov 1999). Our data shows that after 20-25 years of inhabiting of Eastern Ukraine P. $k$. lepidus has formed a mostly female-dominated population that looks unpredictable in the light of the hypothesis mentioned above. In newly formed wintering areas, the ratio of males is often higher (Strelkov 1999; Rakhmatulina 2000; Russo 2002; Snit'ko 2007; Estók 2007; Vlaschenko 2008; Ibáňez et al. 2009). However, we observed some variability in the sex ratio between large groups of $P$. $k$. lepidus and individuals or smaller groups (Fig. 5A). These distinctions may be explained by the fact that females prefer to hibernate and aggregate in bigger groups, while males tend to winter separately or in small groups. For most European bat species, the sex ratio at birth is estimated to be 1:1 (Strelkov 1999; Rakhmatulina 2000) with some rare exceptions, such as shifting to male-dominated during periods of overpopulation (Rakhmatulina 2005). The sex ratio in first-year individuals in the largest groups (Fig. 6B) and among bats found individually (Fig. 5B) in our sample is equal to $1: 1$ in line with previously reported findings. This balanced sex ratio observed in first-year individuals of P. k. lepidus demonstrates that Eastern Ukraine population has not yet reached the level of overpopulation. Three factors may explain the overall tendency towards a female-dominated sex ratio evident in our sample. First, the life expectancy of females tends to be higher than that of males (potentially due to winter roost selection and male tendency to hibernate separately which is more riskier than in large groups). Second, since it is males who tend to disperse from their natal colony, they bear the risks associated with lost their lives in long-distance movements. Third, the observed sex ratio may be biased due to the number of large groups among which the ratio of females was higher than in the total sample. We observed a statistically significant pattern between the proportion of females in a group and the longitude and latitude of that group's origin. The proportion of females in both age groups increases from South to North and from West to East (Table 2). Our first scenario mentioned above can potentially explain the longitudinal gradient (decreasing ratio of males northward and eastward). Males, wintering individually or in small groups in aboveground roosts are more vulnerable to the colder northern and eastern winters and as a result experience higher mortality.

Pipistrellus $k$. lepidus is a species originating from the semi-arid biomes of Central Asia and is adapted for living in semi-desert or even desert conditions. Winters in that area vary from continentally harsh to warm and dry. European bats may be broadly divided according to their roost preferences into "overground" and "underground" hibernators. Overground hibernators employ less protected roosting sites and are more flexible in their winter behavior. This group of Northern Hemisphere bats can wake from torpor during winter to rehydrate and even hunt (e.g. Kaňuch et al. 2005; Lausen \& Barclay 2006b; Zahn \& Kriner 2014). P. k. lepidus is a typical overground hibernator and likely overwintered in rock crevices on its home range in Central Asia. This capacity of $P$. $k$. lepidus for frequent winter arousals provides opportunities to compensate for dehydration brought on by roosting in low humidity buildings. Moreover, $P$. $k$. lepidus continue foraging (or flying out of roosting sites) until the early freezing weather, during thaws, and in early spring (our unpublished observations). In areas of human settlements $P$. $k$. lepidus usually has access to liquid water year-round, especially so in big cities that are warmer due to the urban heat island effect. The percentage of body mass lost (17$20 \%$ ) by P. $k$. lepidus over three months of winter hibernation is similar to that of many underground hibernators such as Myotis daubentonii, Barbastella 
barbastellus and Rhinolophus ferrumequinum (e.g. Lesinski 1986; Kokurewicz 2004; Kim et al. 2019).

\section{Body mass and forearm length analysis}

Previous studies have shown (Sachanowicz et al. 2017) that P. k. lepidus exhibits a higher summer body mass (females $7.5 \mathrm{~g}$, males $7.4 \mathrm{~g}$ ) than its conspecific P. k. kuhlii (females $7.1 \mathrm{~g}$, males $6.4 \mathrm{~g}$ ) (Sachanowicz et al. 2017). Winter body mass for Tunisian P. k. kuhlii does not exceed $8 \mathrm{~g}$, and on average is closer to $6 \mathrm{~g}$ (Dalhoumi et al. 2016), far lower than in Eastern Ukraine and supports Sachanowicz et al. 2017 idea that $P$. $k$. lepidus is bigger taxon. The sexual dimorphism in body mass shown in our study (decrease in mass from adult females, through thisyear females and adult males to the lightest this-year males, Fig. 8) is well documented among other European bat species (see Kokurewicz 2004). The sexual dimorphism in forearm length showed the same pattern as body mass. Our measurements of forearm length produced somewhat larger numbers with a much wider range than previously reported for $P$. $k$. lepidus from Ukraine and Poland (Sachanowicz et al. 2017). For females, the average length was $36 \mathrm{~mm}$ (range: $31.8-39 \mathrm{~mm}$ ) and for males it was $35.5 \mathrm{~mm}$ (range: $33.2-37.8 \mathrm{~mm}$ ) while previously reported lengths were $35.8 \mathrm{~mm}$ (range: $34.3-36.8 \mathrm{~mm}$ ) for females and $35.3 \mathrm{~mm}$ (range: $33.7-37.2 \mathrm{~mm}$ ) for males (Sachanowicz et al. 2017). Despite these differences, the range of measurements within our sample (except for adult females) is well within the previously documented forearm length range of 30.0-38.0 mm for this taxon Sachanowicz et al. 2017). Our results support the argument presented in Sachanowicz et al. 2017 that $P$. k. lepidus is the largest representative of the genus Pipistrellus in Europe.

We hypothesized that each settlement has a sedentary population of $P$. $k$. lepidus, that possibly isolate from each other. Contrary to our expectations we did not detect any significant differences between wintering groups of $P$. $k$. lepidus from different settlements, with the sole exception of Druha Ivanivka village (group number 18, Fig. 7), which may be biased by some factors. We also tested whether the level of light-pollution in each settlement has any effect on the forearm length of local bats. Past studies have examined the effect that streetlights and other forms of urban illumination on the hunting success of P. k. lepidus (e.g. Maxinová et al. 2016) and shown a positive correlation between bat cranial size and light pollution (Tomassini et al. 2013). Contrary to our expectations (except for Druha Ivanivka, a tiny village) we did not observe any significant correlation between light pollution and forearm length of $P$. k. lepidus from Eastern Ukraine.

\section{Threats and conservation}

The 1,301 P. k. lepidus that contributed to this study were animals condemned to death. Were it not for the intervention of activists, volunteers, and the staff at the BRC-FE not one of these bats would have survived the winter. The main threats to bats hibernating in buildings are building renovations and window upgrades. Almost half of the groups in this study were acquired during window renovations $(n=15)$. In Ukraine, this sort of work is often done in the wintertime, thus, it is particularly dangerous to bats as workers expell them during winter weather. The installation or upgrade of heat-insulation in buildings can seal the entrances to bat roosts and trap hibernating bats. Other common dangers for bats include injuries (broken forearm or fingers, holes in wing membranes, trauma to head or ears, limb inflammation) and dehydration.

Human activity in urban areas poses many direct and indirect threats to bats that are absent in natural or semi-natural landscapes. Direct harm includes the accidental or direct killing of bats by individuals, the spread diseases (Frick et al. 2016), roost site loss or disturbance (Frick et al. 2019) and deaths due to collisions with infrastructural facilities such as wind turbines (O'Shea et al. 2016). The indirect threats are habitat loss or modification, climate change (Frick et al. 2019), growth of urban areas, deforestation, physical and chemical pollution, and ecological traps (Russo \& Ancillotto 2015; Vlaschenko et al. 2019). However, conservation efforts have resulted in population recovery among some species (Froidevaux et al. 2017) and many non-governmental and governmental organizations worldwide are involved in bat rescue and rehabilitation (e.g. Racey 2013). Their efforts include helping and rescuing animals as well as educating the public about the importance of bats and raising awareness about the harm caused by ecological traps (Vlaschenko et al. 2019).

\section{ConClusions AND ReCommendations}

The successful growth of $P$. k. lepidus populations in step with expanding urban areas in Europe is an interesting agenda for further research. It is a 
well-established fact that European bats are a threatened group of vertebrates (e.g. Jones et al. 2009; Russo \& Jones 2015) with plenty of evidence of population decline throughout the late $20^{\text {th }}$ (e.g. Stebbings 1988; Hutson et al. 2001) and early $21^{\text {st }}$ centuries (Van der Meij et al. 2014; Barlow et al. 2015). In light of this, the population expansion of $P$. k. lep$i d u s$ is a remarkable example of successful adaptation among European bats. We recorded numerous winter aggregations of $P$. $k$. lepidus in all types of settlements from little villages to a metropolis of 1.5 million human inhabitants. If we make a liberal extrapolation from our data, we can assume that each of the human settlements in Ukraine is home to somewhere between 50 and 100 P. k. lepidus (this is likely an underestimation). Given that there are 460 cities and towns, 28,457 villages and 884 other settlements in Ukraine, we estimate the Ukrainian population of P. k. lepidus to total between one and a half to three millions individuals. Extrapolating further from the above calculations, we can estimate the total bat-biomass as well as the quantity of insects required to support this population to both lie in the tens of thousands of tons. In conclusion, we believe that for the last 20-25 years $P$. k. lepidus has inhabited both urban and rural landscapes throughout Eastern Europe and established a population numbering in the millions which is capable of consuming tens of thousands of tons of insects per annum.

\section{ACKNOWLEDGMENTS}

The authors would like to thank people who rescued bats in different settlements: Ksenia Lisnychuk, Victor Svinaryov, Alla Svinaryova, Tetiana Davydova, Olesia Kulyk, Natalia Verbytska, Galyna Kushenko, Andriy Tupikov, Olha Shapovalova and others. We are also grateful to a large number of our colleagues, employers, volunteers, and alumni for putting up with the exhausting daily routine at the Bat Rehabilitation Center of Feldman Ecopark: Kseniia Kravchenko, Viktor Kovalov, Olena Holovchenko, Ihor Tovstukha, Andriy Schnakenberg, Mykhailo Shlakhter, Alisa Yehorova, Anna Suvorova, Tatiana Yurieva and all the others. The Bat Rehabilitation Center of Feldman Ecopark is funded in large part by the International Charity Foundation "Oleksandr Feldman Foundation".

\section{CORRESPONDING AUTHOR}

*guckov.vitaliy@gmail.com

\section{Supplementary Materials}

The raw dataset available on the GBIF website https://doi.org/10.15468/3dljm6 (Hukov et al. 2020).

\section{REFERENCES}

Adams, L., VanDruff, L., Luniak, M. (2005) Techniques for wildlife investigations and management, Edition: Sixth. In: Clait E. Braun (Eds.), Managing urban habitats and wildlife (pp. 714-739). The Wildlife Society. Ancillotto, L., Tomassini, A., Russo, D. (2015) The fancy city life: Kuhl's pipistrelle, Pipistrellus kuhlii, benefits from urbanization. Wildlife Research, 42, 598-606.

Andriollo, T., Naciri, Y. \& Ruedi, M. (2015) Two mitochondrial barcodes for one biological species: the case of European Kuhl's pipistrelles (Chiroptera). PLoS ONE, 10(8), e0134881.

Barlow, K.E., Briggs, P.A., Haysom, K.A., Hutson, A.M., Lechiara, N.L., Racey, P.A., et al. (2015) Citizen science reveals trends in bat populations: the National Bat Monitoring Programme in Great Britain. Biological Conservation, 182, 14-26.

Benda, P., Andriollo, T., Ruedi, M. (2015) Systematic position and taxonomy of Pipistrellus deserti (Chiroptera: Vespertilionidae). Mammalia, 79(4), 419-438.

Bilushenko, A. (2013) The current status of Kuhl's pipistrelle Pipistrellus kuhlii (Chiroptera: Vespertilionidae) in the central forest-steppe of Ukraine. Vestnik zoologii, 47(4), 343-349.

Bogdanowicz, W. (2004) Handbuch der Saeugetiere Europas. Fledertiere II In: J. Niethammer \& F. Krapp (Eds.), Pipistrellus kuhlii (Kuhl, 1817) - Weissrandfledermaus (pp. 875-908). Aula-Verlag.

Celuch, M. \& Ševčik, M., (2006) First record of Pipistrellus kuhlii (Chiroptera) from Slovakia. Biologia, Bratislava, 61, 637-638.

Dalhoumi, R., Aïssa, P., Aulagnier, S. (2016) Bat species richness and activity in Bou Hedma National Park (central Tunisia). Turkish Journal of Zoology, 40(6), 864-875.

Estók, P. (2007) Seasonal changes in the sex ratio of Nyctalus species in North-East Hungary. Acta zoologica Academiae Scientiarum Hungaricae, 53(1), 89-95.

Frick, W.F., Puechmaille, S.J. \& Willis, C.K.R. (2016) Bats in the Anthropocene: Conservation of Bats in a Changing World. In: C.C. Voigt \& T. Kingston (Eds.), White-nose syndrome in bats (pp. 245-262). Springer International Publishing.

Frick, W.F., Kingston, T. \& Flanders, J.A. (2019) Review of the major threats and challenges to global bat conservation. Annals of the New York Academy of Sciences, 1469(1), 1-21. 
Froidevaux, J.S.P., Boughey, K.L., Barlow, K.E., Jones, G. (2017) Factors driving population recovery of the greater horseshoe bat (Rhinolophus ferrumequinum) in the UK: Implications for conservation. Biodiversity and Conservation, 1-21.

Gashchak, S., Vlaschenko, A., Naglov, A., Kravchenko, K., Prylutska, A. (2013) Bats fauna of the Exclusion Zone in concern of assessment of environmental value of its areas. Problems of Chernobyl Exclusion Zone, 11, 56-78, (in Russian).

Gavris, G., \& Kotserzhinskaia, I. (2002) Record of the Kuhl's pipistrelle Pipistrellus kuhlii (Chiroptera, Vespertilionidae) on the northern boundary of the range in Ukraine. Vestnik zoologii, 36(6), 50, (in Russian).

Godlevskaya, L. (2012) Results of the work of the bat contact-centre (Ukraine). Scientists of the Vernadsky Tauride National University, series "Biology, Chemistry", 25(64), 4, 12-20.

Godlevska, L. (2015) Results of the work of the Kyiv Bat contact-centre in 2012-2015. Proceedings of the Theriological School, 13, 11-19.

Godlevska, L. \& Rebrov, S. (2018) Bats of the Left-Bank Dnipro Region in the northern part of Ukraine. Theriologia Ukrainica, 16, 25-50.

Grimm, N.B., Faeth, S.H., Golubiewski, N.E., Redman, C.L., Wu, J., Bai, X., et al. (2008) Global change and the ecology of cities. Science, 319, 756-760.

Hukov, V., Kovalov, V., Suvorova, A., Rodenko, O., Holovchenko, O. (2019) Structure of bat assemblage in an oak forest on the border of a big urban area, with special focus on Great Noctule Bat (Nyctalus lasiopterus Schreber, 1780). Proceedings of the 14th International young scientists' conference (27-29 November 2019, Kharkiv, Ukraine), Publisher V. N. Karazin KhNU, 168-169.

Hukov, V., Prylutska, A., Timofieieva, O., Rodenko, O., Moiseienko, M., Bohodist, V., Domanska, A., Kravchenko, K., Vlaschenko, A. (2020). Winter colonies of Kuhl's bat (Pipistrellus kuhlii) in Ukraine, 2013-2020. Version 1.2. Bat Rehabilitation Center of Feldman Ecopark. Occurrence dataset https://doi. org/10.15468/3dljm6

Hutson, A.M., Mickleburgh, S.P. \& Racey, P.A. (2001) Microchiropteran Bats - Global Status Survey and Conservation Action Plan. IUCN, Gland.

Hutterer, R., Ivanova, T., Meyer-Cords, C.H., Rodrigues, L. (2005) Bat migration in Europe. A review of banding data and literature.

Ibáñez, C., Guillén, A., Agirre-Mendi, P.T., Juste, J., Schreur, G. (2009) Sexual segregation in iberian noctule bats. Journal of Mammalogy, 90(1), 235-243.
Jones, G., Jacobs, D.S., Kunz, T.H., Racey, P. (2009) Carpe noctem: the importance of bats as bioindicators. Endangered Species Research, 8(1), 93-115.

Jung, K. \& Kalko, E. (2011) Adaptability and vulnerability of high flying Neotropical aerial insectivorous bats to urbanization. Diversity and Distributions, 17(2), 262-274.

Jung, K.G. \& Threlfall, C. (2015) Urbanisation and Its Effects on Bats - A Global Meta-Analysis. In: C. Voigt \& T. Kingston (Eds.), Bats in the Anthropocene: Conservation of Bats in a Changing World (pp. 13-33). Springer Open.

Juste, J. \& Paunović, M. (2016) Pipistrellus kuhlii. The IUCN Red List of Threatened Specie. Retrieved from: https://www.iucnredlist.org/species/17314/22132946

Kaňuch, P., Janečková, K. \& Krištín, A. (2005) Winter diet of the noctule bat Nyctalus noctula. Folia Zoologica, 54(1-2), 53-60.

Kerth, G., Wagner, M., König, B. (2001) Roosting together, foraging apart: information transfer about food is unlikely to explain sociality in female Bechstein's bat (Myotis bechsteinii). Behavioral Ecology and Sociobiology, 50, 283-291.

Kim, S.S., Choi, Y.S. \& Yoo, J.C. (2019) Regional differences in winter activity of hibernating greater horseshoe bats (Rhinolophus ferrumequinum) from Korea. Journal of Ecology and Environment, 43, 2.

Kokurewicz, T. (2004) Sex and Age Related Habitat Selection and Mass Dynamics of Daubenton's Bats Myotis daubentonii (Kuhl, 1817) Hibernating in Natural Conditions. Acta Chiropterologica, 6(1), 121-144.

Kondratenko, O.V. (1999) The first record of Kuhl's pipistrelle (Pipistrellus kuhlii) in Luhansk oblast (Eastern Ukraine). Vestnik zoologii, 33(3), 96, (in Ukrainian).

Kovalov, V., Hukov, V. \& Rodenko, O. (2019) New record of Nyctalus lasiopterus (Schreber, 1780) in Ukraine with a new confirmation of carnivory. North-Western Journal of Zoology, 15(1), 91-95.

Kravchenko, K., Vlaschenko, A.S., Prylutska, A.S., Shuvaev, V., Rodenko, O., Hukov, V. (2017a) Year-round monitoring of bat records in an urban area: Kharkiv (NE Ukraine), 2013, as a case study. Turkish Journal of Zoology, 41(3), 530-548.

Kravchenko, K., Vlaschenko, A.S., Rodenko, O., Belovetskaya, S. (2017b) The results of all-winter rehabilitation of Nyctalus noctula: a case study (Kharkiv, NE Ukraine). In: 5th International Berlin Bat Meeting (Leibniz Institute Zoo and Wildlife research, 24-26 February 2017, Berlin, Germany). 
Lada, G. (2010) Finding of the Kuhl's pipistrelle (Pipistrellus kuhlii) in the Tambov region. Zoological journal, 89(7), 888-890.

Lausen, C. \& Barclay, R. (2006a) Benefits of living in a building: big brown bats (Eptesicus fuscus) in rocks versus buildings. Journal of Mammalogy, 87(2), 362370.

Lausen C. \& Barclay R. (2006b) Winter bat activity in the Canadian prairies. Canadian Journal of Zoology, 84, 1079-1086.

Lesinski, G. (1986) Ecology of Bats Hibernating Underground in Central Poland. Acta Theriologica, 31(37), 507-521.

Maxinová, E., Kipson, M., Nad’o, L., Hradická, P., Uhrin, M. (2016) Foraging Strategy of Kuhl's Pipistrelle at the Northern Edge of the Species Distribution. Acta Chiropterologica, 18(1), 215-222.

McKinney, M. (2008) Effects of urbanization on species richness: A review of plants and animals. Urban Ecosystems, 11, 161-176.

Michálek, B., Šrámek, P., Hotový, J. (2017) First record of Pipistrellus kuhlii in Bohemia, Czech Republic (Chiroptera: Vespertilionidae). Lynx, n. s. (Praha), 48, 207-210.

O'Shea, T.J., Cryan, P.M., Hayman, D.T.S., Plowright, R.K., Streicker, D. (2016) Multiple mortality events in bats: a global review. Mammal Review, 46, 175190.

Panchenko, P. \& Godlevska, L. (2018) Data on the bat fauna of the Northern Black Sea Region based on results of the work of bat contact centres. Theriologia Ukrainica, 16, 120-126.

Popczyk B., Lesiński G., Baumann, A., Wojtowicz, B. (2008) Kuhl's pipistrelle, Pipistrellus kuhlii (Kuhl, 1817) or Pipistrellus lepidus Blyth, 1845, in Central Poland - accidental record or a result of expansion? Nyctalus (N.F.) Berlin, 13, Heft 4, S, 13, 279-281.

Prylutska, A.S. \& Vlaschenko, A.S. (2013) Material to the bat distribution on the base of results of contact-center in Kharkov (2008-2013). "Biological systems", Proceedings of Chernovtsy National University, 5(4), 532-537, (in Russian).

Racey, P.A. (2013) Bat conservation: past, present and future. In: R.A. Adams \& S.C. Pedersen (Eds.), Bat Ecology, Evolution and Conservation (pp. 517-532). 1 st ed. New York, USA, Springer.

Rakhmatulina, I. K. (2000) Sex ratio in bat populations in the Eastern Transcaucasus. Plecotus et al., 3, 50-76, (in Russian with English summary).
Rakhmatulina, I.K. (2005) Bats of Azerbaijan (Fauna, ecology, zoogeography). Baku, Institute of Zoology, National Academy of Sciences of Azerbaijan, (In Russian).

Rebrov, S. (2012) Records of the pipistrelle bats (Pipistrellus) in Luhansk region in the shelter of anthropogenic origin. In: Zagorodniuk I. \& Selunina Z. (Eds.), Abstracts of Ukr. Therio. Soc, Hola Prystan, Theriofauna of Protected Areas and Mammal Protection., 60, (Novitates Theriologicae; Pars 8).

Russo, D. (2002) Elevation affects the distribution of the sexes in Daubenton's bats Myotis daubentonii (Chiroptera: Vespertilionidae) from Italy. Mammalia, 66, 543-551.

Russo, D. \& Ancillotto, L. (2015) Sensitivity of bats to urbanization: a review. Mammalian Biology, 80, 205212.

Russo, D. \& Jones, G. (2015) Bats as bioindicators: an introduction. Mammalian Biology, 80(3), 157-158.

Sachanowicz, K., Wower, A. \& Bashta, A. (2009) Further range extension of Pipistrellus kuhlii (Kuhl, 1817) in Central and Eastern Europe. Acta Chiropterologica, 8, 543-548.

Sachanowicz, K., Piskorski, M. \& Tereba, A. (2017) Systematics and taxonomy of Pipistrellus kuhlii (Kuhl, 1817) in Central Europe and the Balkans, Zootaxa, 4306(1), 053-066.

Shpak, A. \& Larchenko, A. (2016) Range expansion of Kuhl's pipistrelle (Pipistrellus kuhlii) into Belarus. Proceedings of the Theriological School, 14, 99-102.

Smirnov, D.G. \& Vehnik, V.P. (2011) About the current distribution Pipistrellus kuhlii (Chiroptera: Vespertilionidae) in the Volga region. Volga Region Ecological Journal, 2, 193-202, (in Russian).

Smirnov, N., Skilsky, I. \& Timakov, A. (2012) Pipistrellus kuhlii (Chiroptera, Vespertilionidae) - the First Finding in the Ukrainian Carpathians. Vestnik zoologii, 46(5), 472, (in Ukrainian).

Snit'ko, V.P. (2007) Seasonal spatial differentiation of sex groups in populations of resident bat species (Chiroptera, Vespertilionidae) in the Southern Urals. Russian Journal of Ecology, 38, 334-340.

Stebbings, R.E. (1988) Conservation of European Bats. Christopher Helm, London.

Strelkov, P.P. (1973) Pipistrellus kuhlii (Natterer, 1819) in the Middle Asia. Vestnik Zoologii 2, 82-85, (In Russian).

Strelkov, P.P., Unkurova, V.I., Medvedeva, G.A. (1985) New data on Pipistrellus kuhlii and dynamics of its range in the USSR. Zoologichesky zhurnal, 64(1), 8797. 
Strelkov, P.P. \& Il'in, V.Y. (1990) The bats (Chiroptera, Vespertionidae) of the south Middle Volga and Lower Volga provinces. Annals of the Zoological Institute of Academy of Science of USSR, 225, 42-167, (in Russian).

Strelkov, P.P. (1999) Sex ratio in breeding season in adult individuals of long-distant migrant bats (Chiroptera, Vespertilionidae) of Eastern Europe and adjacent territories. Zoologicheskiy zhurnal, 78(12), 1441-1454, (in Russian with English summary).

Tomassini, A., Colangelo, P., Agnelli, P., Jones, G., Russo, D. (2013) Cranial size has increased over 133 years in a common bat, Pipistrellus kuhlii: a response to changing climate or urbanization? Journal of Biogeography, 41(5), 944-953.

Van der Meij, T., Van Strien, A.J., Haysom, K.A., Vintulis, V., Dekker, J., Russ, J. (2014) Return of the bats? A prototype indicator of trends in European bat populations in underground hibernacula. Mammalian Biology - Zeitschrift fur Saugetierkunde, 80(3), 170-177.

Vlaschenko, A.S. (2008) Sex ratio in four bats species in North-Eastern Ukraine. Journal of V.N. Karazin's National University. Series: "Biology", 814(7), 65-73, (in Russian).

Vlaschenko, A.S., Godlevskaya, L.V., Kravchenko, K., Tyshchenko, V.M., Gukasova, A.S., Sudakova, M.V. (2012) Contribution to bat fauna of Holosiyivsky National Nature Park. Nature Reserves in Ukraine, 18(12), 51-58, (in Russian).
Vlaschenko, A.S. \& Plylutska, A.S. (2018) The Bat Rehabilitation Center of the "Feldman Ecopark", Kharkiv, Ukraine $\backslash$ Das Bat Rehabilitation Center des „Feldman Ecoparks“, Charkiw, Ukraine. Nyctalus (N.F.) Berlin, 19(2), 158-161.

Vlaschenko, A.S., Prylutska, A.S., Kravchenko, K., Rodenko, O., Hukov, V., Timofieieva, O., et. al. (2020) Regional recaptures of bats (Chiroptera, Vespertilionidae) ringed in Eastern Ukraine. Zoodiversity, 54(1), 53-66.

Voigt, C.C., Phelps, K., Aguirre, L.F., Schoeman, C., Vanitharani, J., Zubaid, A., et al. (2016) Bats and Buildings: The Conservation of Synanthropic Bats. In: Voigt C.C. \& T. Kingston (Eds.), Bats in the Anthropocene: Conservation of Bats in a Changing World (pp. 427-462). Springer International Publishing.

Zagorodniuk, I. (2018) A game against natural selection: cases of hibernation of migrant bat species in their summering range in Eastern Ukraine. Theriologia Ukrainica, 16, 111-119.

Zahn, A., Kriner, E., (2014) Winter foraging activity of Central European Vespertilionid bats. Mammalian Biology - Zeitschrift fur Saugetierkunde, 81(1), 40-45. 


\section{APPENDIX}

Table 1. Places and building conditions where groups of P.k.lepidus were found.

\begin{tabular}{|c|c|c|c|c|c|c|c|c|c|c|}
\hline № & Date & City & Coordinates & Address & $\begin{array}{l}\text { Height } \\
\text { of the } \\
\text { building }\end{array}$ & $\begin{array}{l}\text { Floor } \\
\text { where } \\
\text { bats } \\
\text { were } \\
\text { found }\end{array}$ & $\begin{array}{l}\text { The } \\
\text { material } \\
\text { of the } \\
\text { building }\end{array}$ & $\begin{array}{l}\text { Type of the } \\
\text { building }\end{array}$ & $\begin{array}{l}\text { Conditions } \\
\text { of finding }\end{array}$ & $\begin{array}{l}\text { Number } \\
\text { of bats }\end{array}$ \\
\hline 1 & 18.01 .2013 & $\begin{array}{l}\text { Oleksan- } \\
\text { drivka }\end{array}$ & $\begin{array}{l}48.706421, \\
36.909343\end{array}$ & unknown & 1 & 1 & & & other & 6 \\
\hline 2 & 13.01 .2014 & Kharkiv & $\begin{array}{l}\text { 49.987721, } \\
36.232106\end{array}$ & \begin{tabular}{|l} 
Rozy Ly- \\
uksemburg \\
Sq., 10
\end{tabular} & 6 & & $\begin{array}{l}\text { concrete } \\
\text { prefab- } \\
\text { ricated } \\
\text { block }\end{array}$ & administrative & behind frames & 1 \\
\hline 3 & 15.01 .2014 & Kharkiv & $\begin{array}{l}50.023714 \\
36.241078\end{array}$ & $\begin{array}{l}\text { Novgorodska } \\
\text { St., } 85\end{array}$ & 4 & 4 & brick & administrative & behind frames & 1 \\
\hline 4 & 21.01 .2014 & Dvorichna & $\begin{array}{l}49.849921 \\
37.682740\end{array}$ & \begin{tabular}{|l} 
Slobozhanska \\
St.,10
\end{tabular} & 3 & & brick & administrative & & 1 \\
\hline 5 & 16.02 .2014 & Kharkiv & $\begin{array}{l}49.967044, \\
36.221711\end{array}$ & \begin{tabular}{|l|} 
Moskalevska \\
St.,99
\end{tabular} & 5 & & $\begin{array}{l}\text { concrete } \\
\text { prefab- } \\
\text { ricated } \\
\text { block }\end{array}$ & industrial & & 1 \\
\hline 6 & 28.11 .2014 & Solonytsivka & $\begin{array}{l}49.988558 \\
36.064723\end{array}$ & $\begin{array}{l}\text { Pushkina } \\
\text { St., } 14\end{array}$ & 9 & & $\begin{array}{l}\text { concrete } \\
\text { prefab- } \\
\text { ricated } \\
\text { block }\end{array}$ & residential & behind frames & 1 \\
\hline 7 & 10.12 .2015 & Merefa & $\begin{array}{l}49.814097 \\
36.061876\end{array}$ & unknown & 1 & 1 & & & other & 13 \\
\hline 8 & 14.12 .2015 & Kramatorsk & $\begin{array}{l}48.729194 \\
37.588318\end{array}$ & $\begin{array}{l}\text { Parkova } \\
\text { St.,12 }\end{array}$ & 1 & 1 & brick & industrial & behind frames & 20 \\
\hline 9 & 19.01 .2016 & Kharkiv & $\begin{array}{l}49.974514 \\
36.252672\end{array}$ & $\begin{array}{l}\text { Gagarina } \\
\text { Ave.,56 }\end{array}$ & 8 & 8 & brick & residential & behind frames & 8 \\
\hline 10 & 22.01 .2016 & Chuhujiv & $\begin{array}{l}49.842164 \\
36.687950\end{array}$ & \begin{tabular}{|l} 
Kozheduba \\
St.,15
\end{tabular} & 5 & 4 & $\begin{array}{l}\text { concrete } \\
\text { prefab- } \\
\text { ricated } \\
\text { block }\end{array}$ & residential & & 1 \\
\hline 11 & 08.12 .2016 & Lysychansk & $\begin{array}{l}48.861301 \\
38.475366\end{array}$ & $\begin{array}{l}\text { kv. } 40 \text { rokiv } \\
\text { Peremohy, } 19\end{array}$ & 4 & 2,3 & brick & administrative & behind frames & 3 \\
\hline 12 & 16.02 .2017 & $\begin{array}{l}\text { Jelyzavet- } \\
\text { ivka }\end{array}$ & $\begin{array}{l}48.618285 \\
34.650950\end{array}$ & $\begin{array}{l}\text { Tsentralna } \\
\text { Sq.,3 }\end{array}$ & 1 & 1 & brick & administrative & behind frames & 18 \\
\hline 13 & 21.02 .2017 & Kyseli & $\begin{array}{l}49.429227, \\
36.437761\end{array}$ & unknown & 1 & 1 & & & other & 1 \\
\hline 14 & 25.02 .2017 & Kharkiv & $\begin{array}{l}49.989721, \\
36.235902\end{array}$ & $\begin{array}{l}\text { Slyusarnaya } \\
\text { St.,1 }\end{array}$ & 2 & 2 & brick & administrative & behind frames & 23 \\
\hline 15 & 10.12 .2017 & $\begin{array}{l}\text { Kro- } \\
\text { pyvnytskyj }\end{array}$ & $\begin{array}{l}48.519698 \\
32.286683\end{array}$ & $\begin{array}{l}\text { Poltavska } \\
\text { St., } 79\end{array}$ & 9 & & $\begin{array}{l}\text { brick } \\
\text { buildings }\end{array}$ & residential & behind frames & 23 \\
\hline 16 & 20.12 .2017 & Karlivka & $\begin{array}{l}49.453644 \\
35.104244\end{array}$ & $\begin{array}{l}\text { Promyslova } \\
\text { St.,43 }\end{array}$ & 2 & 2 & brick & administrative & behind frames & 641 \\
\hline
\end{tabular}


Vitalit Hukov et al. - Wintering of an Urban Bat (Pipistrellus Kuhlit lepidus) in Recently Occupied Areas

\begin{tabular}{|c|c|c|c|c|c|c|c|c|c|c|}
\hline 17 & 25.12 .2017 & Chuhujiv & $\begin{array}{l}49.841721, \\
36.686158\end{array}$ & $\begin{array}{l}\text { Kozheduba } \\
\text { St., } 19\end{array}$ & 5 & & $\begin{array}{l}\text { concrete } \\
\text { prefab- } \\
\text { ricated } \\
\text { block }\end{array}$ & residential & on balcony & 1 \\
\hline 18 & 27.12 .2017 & $\begin{array}{l}\text { Druha } \\
\text { Ivanivka }\end{array}$ & $\begin{array}{l}49.002268, \\
36.866430\end{array}$ & Myru St.,8 & & & & administrative & behind frames & 58 \\
\hline 19 & 11.02 .2018 & Lozova & $\begin{array}{l}48.894265, \\
36.290771\end{array}$ & $\begin{array}{l}\text { Svobody } \\
\text { St.,24 }\end{array}$ & & & brick & industrial & & 1 \\
\hline 20 & 04.03 .2018 & Kramatorsk & $\begin{array}{l}48.739981, \\
37.600003\end{array}$ & unknown & & & & & behind frames & 92 \\
\hline 21 & 16.12 .2018 & Hrebinky & $\begin{array}{l}49.945734, \\
30.199649\end{array}$ & \begin{tabular}{|l|} 
Bilotserkivs- \\
ka St.,5
\end{tabular} & & & & industrial & other & 3 \\
\hline 22 & 20.12 .2018 & Kharkiv & $\begin{array}{l}49.972332, \\
36.220316\end{array}$ & \begin{tabular}{|l} 
Svitlo \\
shakhtarya \\
St.,24
\end{tabular} & 1 & 1 & brick & residential & $\begin{array}{l}\text { inside win- } \\
\text { dow }\end{array}$ & 1 \\
\hline 23 & 12.02 .19 & Kharkiv & $\begin{array}{l}50.041437, \\
36.295035\end{array}$ & \begin{tabular}{|l|} 
Elektroin- \\
strumentalna \\
St.,9
\end{tabular} & 9 & 9 & $\begin{array}{l}\text { concrete } \\
\text { prefab- } \\
\text { ricated } \\
\text { block }\end{array}$ & residential & behind frames & 1 \\
\hline 24 & 02.12 .2019 & $\overline{\text { Lozova }}$ & $\begin{array}{l}48.894265, \\
36.290771\end{array}$ & $\begin{array}{l}\text { Svobody } \\
\text { St.,24 }\end{array}$ & & & brick & industrial & & 1 \\
\hline 25 & 03.12 .2019 & Zaporizhzhia & $\begin{array}{l}47.809357, \\
35.163578\end{array}$ & $\begin{array}{l}\text { Hliserna } \\
\text { St, } 24\end{array}$ & 5 & 3 & brick & residential & behind frames & 9 \\
\hline 26 & 03.12 .2019 & Kharkiv & $\begin{array}{l}50.033121, \\
36.221511\end{array}$ & $\begin{array}{l}\text { Nauky } \\
\text { Av.,60a }\end{array}$ & 4 & 4 & $\begin{array}{l}\text { concrete } \\
\text { prefab- } \\
\text { ricated } \\
\text { block }\end{array}$ & administrative & behind frames & 16 \\
\hline 27 & 03.12 .2019 & Luzhok & $\begin{array}{l}50.079685, \\
36.121971\end{array}$ & unknown & 1 & 1 & & & other & 1 \\
\hline 28 & 05.12 .2019 & Kharkiv & $\begin{array}{l}\text { 49.962981, } \\
36.291609\end{array}$ & $\begin{array}{l}\text { Hordona } \\
\text { St., } 1\end{array}$ & 3 & 1 & brick & administrative & behind frames & 1 \\
\hline 29 & 12.12 .2019 & Sonyachne & $\begin{array}{l}47.406738, \\
37.441300\end{array}$ & Shkilna St.,29 & 2 & 1 & brick & administrative & behind frames & 61 \\
\hline 30 & 23.12 .2019 & Derhachi & $\begin{array}{l}50.110325, \\
36.108109\end{array}$ & $\begin{array}{l}\text { Pershogo } \\
\text { Travnya } \\
\text { St., } 10\end{array}$ & 2 & & brick & administrative & & 2 \\
\hline 31 & 28.12 .2019 & Vilne & $\begin{array}{l}50.215820, \\
29.779836\end{array}$ & $\begin{array}{l}\text { Ternopilska } \\
\text { St.,2 }\end{array}$ & 2 & 2 & brick & administrative & behind frames & 138 \\
\hline 32 & 28.12 .2019 & Kharkiv & $\begin{array}{l}50.004108, \\
36.228275\end{array}$ & $\begin{array}{l}\text { Svobody } \\
\text { Sq., } 4\end{array}$ & 14 & 11 & brick & administrative & $\begin{array}{l}\text { inside win- } \\
\text { dow }\end{array}$ & 1 \\
\hline 33 & 04.01 .2020 & Odesa & $\begin{array}{l}46.476343, \\
30.722821\end{array}$ & unknown & & & & & & 3 \\
\hline 34 & 21.01 .2020 & Melitopol & $\begin{array}{l}46.842938, \\
35.386825\end{array}$ & \begin{tabular}{|l|} 
Interkulturna \\
St., $21 / 1$
\end{tabular} & 4 & & $\begin{array}{l}\text { concrete } \\
\text { prefab- } \\
\text { ricated } \\
\text { block }\end{array}$ & industrial & other & 1 \\
\hline
\end{tabular}


Vitali Hukov et al. - Wintering of an Urban Bat (Pipistrellus Kuhlit lepidus) in Recently Occupied Areas

\begin{tabular}{|c|c|c|c|c|c|c|c|c|c|c|}
\hline 35 & 22.01 .2020 & Mariupol & $\begin{array}{l}47.140264, \\
37.594176\end{array}$ & $\begin{array}{l}\text { Levchenko } \\
\text { St.,1 }\end{array}$ & 3 & & $\begin{array}{l}\text { concrete } \\
\text { prefab- } \\
\text { ricated } \\
\text { block/ } \\
\text { brick }\end{array}$ & industrial & other & 1 \\
\hline 36 & 24.01 .2020 & $\begin{array}{l}\text { Pervo- } \\
\text { mais'kyi }\end{array}$ & $\begin{array}{l}49.399685, \\
36.214714\end{array}$ & Shkilna St. & 2 & & brick & administrative & other & 1 \\
\hline 37 & 03.02 .2020 & Balakliya & $\begin{array}{l}49.450814, \\
36.838333\end{array}$ & \begin{tabular}{|l} 
Travnya \\
St.,19
\end{tabular} & & & & & & 1 \\
\hline 38 & 05.02 .2020 & Mariupol & $\begin{array}{l}47.125236, \\
37.683425\end{array}$ & $\begin{array}{l}\text { Kyjivska } \\
\text { St.,80 }\end{array}$ & 9 & $7-8$ & $\begin{array}{l}\text { concrete } \\
\text { prefab- } \\
\text { ricated } \\
\text { block }\end{array}$ & residential & $\begin{array}{l}\text { inside win- } \\
\text { dow }\end{array}$ & 144 \\
\hline 39 & 21.02 .2020 & Slovjyansk & $\begin{array}{l}48.855394, \\
37.610720\end{array}$ & unknown & & & & & inside window & 1 \\
\hline
\end{tabular}

Table 2. Results of multiple regression analysis where depend variable is forearm length and predictor are sex, age and location of find.

Residuals:

Min 1Q Median 3Q Max

$\begin{array}{lllll}-35.481 & -0.499 & 0.067 & 0.598 & 2.701\end{array}$

\begin{tabular}{|l|l|l|l|l|l|}
\hline \multicolumn{2}{|l|}{ Factors } & Coefficients & SE & t-value & p-value \\
\hline (Intercept) & Male & 35.98051 & 0.07933 & 453.572 & $<2 * 10^{-16}$ \\
\hline \multirow{2}{*}{ Sex } & This-year-born & -0.51441 & 0.13709 & -3.752 & 0.000184 \\
\cline { 2 - 6 } & un & 0.11845 & 0.1 & 1.185 & 0.236463 \\
\hline \multirow{3}{*}{ Location of find } & 31 & -0.18656 & 0.45506 & -0.41 & 0.681913 \\
\cline { 2 - 6 } & 35 & 0.10310 & 0.15485 & 0.666 & 0.505666 \\
\cline { 2 - 6 } & 27 & 0.13891 & 0.12627 & 1.1 & 0.271548 \\
\cline { 2 - 6 } & 29 & 0.25294 & 0.21329 & 1.186 & 0.235919 \\
\cline { 2 - 6 } & 18 & 0.04821 & 0.1278 & 0.377 & 0.706047 \\
\hline \multirow{5}{*}{ Sex:Age } & Male:This-year-born & -0.58961 & 0.18547 & -3.179 & 0.001519 \\
\cline { 2 - 6 } & Male:un & -0.04502 & 0.91098 & -0.049 & 0.960593 \\
\hline
\end{tabular}

Residual standard error: 1.348 on 1099 degrees of freedom

Multiple R-squared: 0.04222 , Adjusted R-squared: 0.0335

F-statistic: 4.844 on 10 and $1099 \mathrm{DF}$, p-value: $7.42 * 10^{-7}$ 
Table 3. Results of multiple regression analysis where depend variable is forearm length and predictor are sex, age and level of light pollution.

Residuals:

Min 1Q Median 3Q Max

$\begin{array}{lllll}-35.460 & -0.492 & 0.065 & 0.622 & 2.928\end{array}$

\begin{tabular}{|l|l|l|l|l|l|}
\hline \multicolumn{2}{|l|}{ Factors } & Coefficients & SE & t-value & p-value \\
\hline (Intercept) & 35.935096 & 0.075538 & 475.725 & $<2^{*} 10^{-16}$ \\
\hline Sex & Male & -0.492319 & 0.135238 & -3.64 & 0.000285 \\
\hline \multirow{2}{*}{ Age } & This-year-born & 0.131708 & 0.096671 & 1.362 & 0.173341 \\
\cline { 2 - 6 } & un & -0.152120 & 0.456540 & -0.333 & 0.739045 \\
\hline \multirow{2}{*}{ Level of light pollution } & 0.009477 & 0.006493 & 1.460 & 0.144682 \\
\hline Sex:Age & Male:This-year-born & -0.021965 & 0.182625 & -0.12 & 0.904286 \\
\hline & Male:un & -0.034920 & 0.912696 & -0.038 & 0.969487 \\
\hline
\end{tabular}

Residual standard error: 1.354 on 1103 degrees of freedom Multiple R-squared: 0.03127 , Adjusted R-squared: 0.026

F-statistic: 5.935 on 6 and 1103 DF, p-value: $4.107^{*} 10^{-}$

Table 4. Results of multiple regression analysis where depend variable is body mass of bats and factors are sex, age and month.

Residuals:

Min 1Q Median 3Q Max

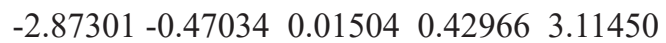

\begin{tabular}{|l|l|l|l|l|l|}
\hline \multicolumn{2}{|l|}{ Factors } & Coefficients & SE & t-value & $\mathrm{p}$-value \\
\hline \multirow{2}{*}{ (Intercept) } & 6.83975 & 0.07687 & 88.980 & $<2^{*} 10^{-16}$ \\
\hline \multirow{2}{*}{ Month } & December & 1.13380 & 0.08187 & 13.849 & $<2^{*} 10^{-16}$ \\
\cline { 2 - 6 } & February & -0.16887 & 0.10151 & -1.664 & 0.09 \\
\hline \multirow{2}{*}{ Sex } & Male & -0.68805 & 0.04908 & -14.020 & $<2^{*} 10^{-16}$ \\
\hline \multirow{2}{*}{ Age } & sad & -0.50054 & 0.04575 & -10.940 & $<2^{*} 10^{-16}$ \\
\cline { 2 - 6 } & un & -0.0459 & 0.21296 & -0.216 & 0.829 \\
\hline
\end{tabular}

Multiple R-squared: 0.4459

Adjusted R-squared: 0.4434

F-statistic: 176.6 on 5 and $1097 \mathrm{DF}$, p-value: $<2.2^{*} 10^{-16}$ 